\title{
形成位相の識別に関する運動学的一考察
}

\author{
朝岡 正雄 ${ }^{1)}$ 佐藤 誠 $^{2)}$ 金谷麻理子 ${ }^{11}$
}

\section{Eine Betrachtung über die Identifizierung der Phasen bei der Bewegungsformung vom Standpunkt der anthropologischen Bewegungslehre}

\author{
Masao Asaoka ${ }^{1}$, Makoto Satoh ${ }^{2}$ und Mariko Kanaya ${ }^{1}$
}

\section{Zusammenfassung}

"Erlernt ist eine Bewegung, wenn der Leib sie verstanden hat, d.h. wenn er sie seiner 'Welt' einverleibt hat, und seinen Leib bewegen heißt immer, durch ihn hindurch auf die Dinge abzielen, ihn einer Aufforderung entsprechen lassen, die an ihn ohne den Umweg über irgendeine Vorstellung ergeht." Mit anderen Worten, es ist nie "unser objektiver Körper, den wir bewegen, sondern stets unser phänomenaler Leib" (Merleau-Ponty 1966). Wenn auf die Problematik des Erlernens von Bewegungen eingegangen werden soll, ist es daher unerläßlich, ein kinästhetisches Bewußtseinserlebnis im Sinne E. Husserls als Betrachtungsgegenstand zu setzen. Aufbauend auf die phänomenologische Methodologie von E. Husserl hat A. Kaneko dazu ein theoretisches Modell aufgestellt, mit dem die Entwicklung der kinästhetischen Vermöglichkeiten im Bewegungserlebnis beschrieben werden kann. A. Kaneko unterscheidet fünf Phasen der Bewegungsformung: 1. Phase der horizontale Intentionalität, 2. Phase der Suche, 3. Phase des zufälligen Zustandekommens, 4. Phase der Schematisierung, 5. Phase der Beherrschung (Kaneko, 2002). In der vorliegende Forschungsarbeit soll nun ein neues Verfahren zur Identifizierung der jeweiligen Phase bei der Bewegungsformung vorgestellt werden. Dazu wurden die Lernprozesse von drei Anfängern beobachtet, wie sie den Handstandüberschlag rückwärts am Boden lernten. Es wurde ein spezifischer Fragebogen ausgearbeitet, um die kinästhetischen Vermöglichkeiten nach Kaneko (2002) zu identifizieren. Der Fragebogen wurde außerdem für die Unterrichtspraxis verwendet. Es konnten so die Phasen der Bewegungsformung, wie die drei Lernenden sie durchliefen, eindeutig beobachtet, belegt und identifiziert werden. Den Lernenden konnten ferner die fehlenden kinästhetischen Vermöglichkeiten als konkretes Lernziel vorgezeigt werden. In einer späteren Arbeit soll unser Fragebogen erweitert werden, so daß die Entstehung von neuen kinästhetischen Vermöglichkeiten auch in der Phase der Beherrschung erfaßt werden kann.

\footnotetext{
1) 筑波大学体育科学系 ₹ 305-8574 茨城県つくば市天王台 1-1-1

2) 沼津工業高等専門学校 干 410-8501 静岡県沼津市大岡 3600 連絡先 朝岡正雄
}

1. University of Tsukuba, Institute of Health \& Sport Sciences

1-1 Tennohdai-1 chome, Tsukuba-shi, Ibaraki 305-8574

2. Numazu College of Technology, Division of Liberal Arts

3600 Ohoka, Numazu-shi, Shizuoka 410-8501

Corresponding author m-asaoka@mse.biglobe.ne.jp 


\section{Key words : Motorisches Lernen, Erlernen von Bewegungen, Bewegungsgestaltung, Lernphase}

(Japan J. Phys. Educ. Hlth. Sport Sci. 49: 557-571, November, 2004)

\section{キーワード：運動学習, 運動習得, 動きつくり， 学習位相, 運動形成}

\section{I 研究の目的}

運動を習得するのは，「身体がその運動を了解 したとき，つまり，身体がそれを自分のく世界 > へと合体したとき」であり，この時に「われわれ が動かすものは，けっしてわれわれの客観的身体 ではなくて，われわれの現象的身体」である（メ ルロー一ポンティ，1967）。それゆえ，運動習得 の問題に立ち入ろうとすれば，「現象的身体に立 ち現れる運動感覚の意識体験」を考察対象として 措定せざるをえない（金子，2002，p. 262）。こ のために，フッサールの「超越論的構成分析」 （木田ほか，1994，pp. 145-146）の方法を用いて， 運動者自身の「志向構造を分析し，どのように私 の蓮動感覚図式を構成しようとしているのかを， その発生地平まで遡源して解明」しょうとしたの が，金子の「発生論的運動分析」である。

金子（2002，p. 38-41）によれば，運動感営図 式の成立には運動感覚能力の存在が前提になって いるという。この意味の運動感覚能力はフッサー ル後期の発生現象学における鍵概念としての「キ ネステーゼ」，すなわち「今ここでの私の身体に おける運動意識」と解される。その際に「対象を そこに現前するものとして直観的に提示する働 き」は「現前化」(Präsentation) と呼ばれる. この現前化の働きはそれ自体の中に分裂を含んで いて，「原現前」(Urpräsentaition）と「共現前」 (Appräsentation）の共働と絡み合いによって成 立している（ヘルト，2000，p. 78）。すなわち， 「志向的体験は，空虚な志向から直観による充実 に向かう目的論的傾向をもっている」（木田ほか, 1994, p. 100）という意識のあり方の先行構造に 基づいて, 過去の経験は「変形された形で蓄積さ
れそれによって描かれた下絵による動機づけの もとで新たな経験の受容が行われる」のである (木田ほか，1994，p. 448)。それゆ之，「現実的 なキネステーゼ」には，「私は動いている」とい う意識だけでなく，「『私はできる』（ich kann） という能力（Vermögen）によって動機づけられ た可能性」を意味する「可能力性」 （Vermöglichkeit）の体系が同時に含まれている (浜渦, 1995, p. 158).

したがって，この意味の運動感覚能力に基づい て構成される運動感覚図式は運動の客観的な展開 の仕方に関する図式的表象を意味しない，ネク夕 イを結ぶことに熟達している人の場合にはそれが どのようになされるのかを視覚的にイメージしな くても上手に遂行できるし，スポーツマンは自分 がどのように運動を遂行しているのかを客観的に 思い浮かべなくても思ったように動くことができ る。つまり，この場合には，順番に行われなけれ ばならない動きを，たとえば「右・左・右」のよ うな簡単な言葉で指示するだけの一連のプランが 存在していて，これを順番に思い浮かべるだけで 複雑な行為の全体はいわば自動的に繰り広げられ ることになる。それゆえ，運動の習得とは，「計 画的にできるようになることを通して組織化する こと」 (Organisieren durch planmäßiges Verfügen）に他ならないのである（Buytendijk, 1956, pp. 280).

このために，金子は，その著『わざの伝承』 （2002）の中で，運動指導に抢ける従来の機械論 的運動分析の問題性を明らかにして，フッサール 現象学の方法を用いて運動体験における「キネス テーゼ的能力」の発生分析を試みたのである。こ の「発生論的運動分析」の対象として，金子 （2002，pp. 451-532）は，学習者自身が運動感覚 図式を発生させる「創発能力」と指導者が学習者 に運動感覚能力の図式化を促して形態発生させる 
「促発能力」の 2 領域を定立し，それぞれの能力 を構成している下位能力の全体像を示して，これ らの下位能力に関する存在論と発生分析を展開し ている。この場合には，金子（2002，p. 415）も 指摘しているように，先行判断を起点として運動 テクストが選び出され，その解釈を通して先行判 断の誤りが修正され，修正された先行判断に基づ いて再び運動テクストが選び直されるという「解 釈学的循環」を通して，解釈の妥当性が高められ る.しかも，この観察者の先行判断は，観察者自 身の運動生活史やその志向対象に対する運動認識 だけでなく，観察対象となっている学習者の運動 形態がどのレベルの形成位相にあるのかに関する 判断に大きく左右される。それゆえ，運動感覚能 力の解釈学的意味分析では，選び出された運動テ クストがどのレベルの運動形成の位相にあるのか をとらえておくことが不可欠となる.このために， 金子（2002，pp. 417-430）は，運動感覚能力の 発生分析に先立って，「原現前」と「共現前」の 絡み合いによって成立している運動感覚能力の図 式化のレベルを「原志向位相」，「探索位相」，「偶 発位相」,「図式化位相」,「自在化位相」の 5 つに 区分して，各々の位相の特徴を詳細に描写してい る.しかし，そこでは，個々の具体的な運動の場 合に, 連動者が運動感覚能力をどのレベルで図式 化しているのかを識別する方法には言及していな い.

それゆえ，本論の目的は，具体的な運動が「で きない」ところから「できる」ようになり，さら に「上手になる」までの形成過程の中で，金子の 意味の「創発能力」の発生様態をとらえる方法を 開発し，これに基づいて個々の学習者の当該の運 動に関する形成位相を識別する方法を確立するこ とにある. 本論の研究を通して具体的な運動の事 例で運動感覚能力の存在と形成位相を識別できる ようになれば，それらの能力を改めて学習対象に 取り上げることによってその時々の形成位相に応 じた最適な学習目標を提示することができるよう になり（金子，2002，p. 481），このことを通し て指導法の画期的な改善が期待される.

\section{II 研究の方法}

\section{1. 研究対象の選定と仮説の導出}

本論では，上に述べた目的を達成するために， 「直接的幇助」（金子，1972）を用いてマット運動 の「後転とび」を習得する過程が研究対象として 選ばれた。「後転とび」は「できる・できない」 が明確に区別でき，しかも「できるようになる」 ことがそれほど難しくはないので, 教科体育の授 業の枠内でも「できない」ところからはじまって 「できるようになる」までのプロセスを観察しう ると考えたからである。それゆえ，本論では，す でに述べた金子の五位相の中の「自在化位相」は 考察の射程外に置かれることになる。

研究に着手するにあたって，本論ではまずはじ めに，「形成位相」と「創発能力の発生分析」に 関する金子（2002，pp. 417-513）の考察を下敷 きにして, 各形成位相とそこで発生する運動感覚 能力の関係づけが試みられた（表1の下段）。さ らに，この関係づけに基づいて，著者自身の体験 を徹底的に振り返ることによって，後転とびの形 成位相の展開にともなう運動感覚能力の発生様態 に関する仮説が導き出された（表1の上段）。

\section{2. 質問紙の作成}

続いて，表1の上段に示した(1)一(10)までの運動 感覚能力が後転とびの習得プロセスにおいてどの ような順序で発生するのかを調查するという目的 で，表 2 に示した質問紙が作成された．表 2 の左 側欄外に○印で示されている番号は，表1の(1)か ら(10)までの運動感覚能力を示している．表2の質 問項目 1 は学習者の後転とびに対する学習志向性 を識別することを目指している．質問項目 2 と 3 では，「原志向的体感能力」の発生に基づいて後 転とびの遂行中にこの技になじめそうな気配を感 じているのかどうかを識別することが意罒されて いる．質問項目 $4 ， 5 ， 6$ は，後転とびの実施中に 「零点体感能力」と「遠近体感能力」に基づいて 自らの移動を確認できるようになっているかどう かを調べるための質問である，さらに，質問項目 
表 1 後転とびの形成位相の展開にともなう運動感覚能力の発生（仮説）

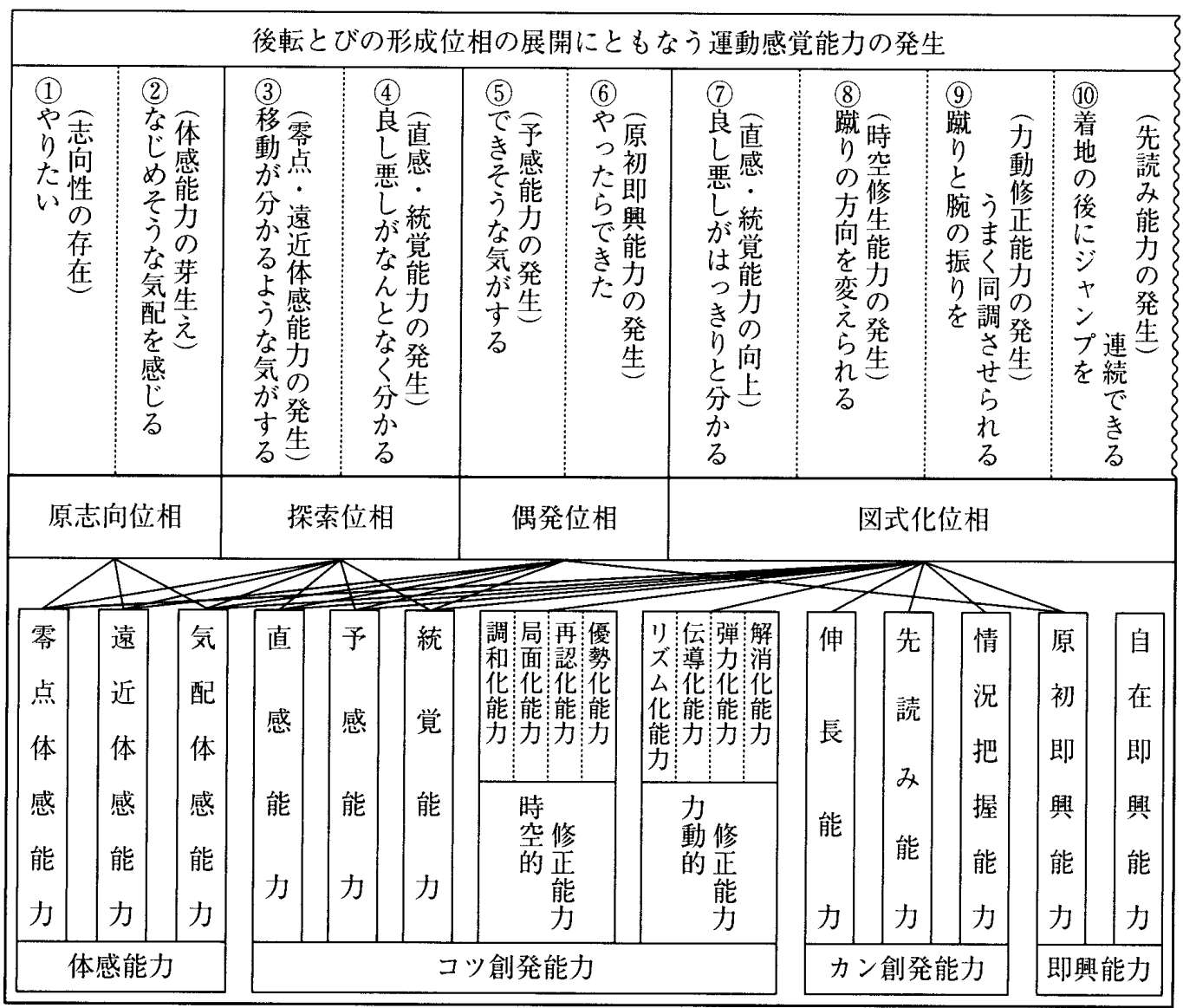

$7,8 ， 9 ， 10$ は主として「直感能力」と「統覚能 力」, 質問項目 11 と 12 は「原初即興能力」と 「予感能力」, 質問項目 13 と 14 は「時空的修正能 力」と「力動的修正能力」, 質問項目 15 は「先読 み能力」の発生に関わっている.

表 1 に示した(1)から(10)の順序で個々の「運動感 覚能力」が発生するという仮説が正しいとすれば, 学習者が極端な学習障害に出会わずに，後転とび の習熟が「原志向位相」から「図式化位相」へと 順調に高まっていった場合には，表2の質問紙の 回答は，学習の進展にともなって回答欄の右から 左へと変化していく傾向を示し，しかもこの傾向 は, 番号の少ない質問項目では学習過程の初期に, 番号の多い質問項目ではそれよりも遅い時期にな って示されるということが予想される。したがっ て，質問紙の回答結果にこのような傾向が確認で きれば，本論で作成された質問紙（表2）を用い ることによって，個々の学習者ごとに後転とびの 形成位相展開の様相を明らかにすることが可能に
なると考えられる。

\section{3. 調查対象の選定と調査の内容}

本論では，平成 15 年度に沼津工業高等専門学 校の 2 年生 3 クラス（M2，C2，S2）を対象にし て行われたマット運動の授業の中から調査対象が 選定された。授業は，学習者自身が「後転とび」, 「前転とび」，「接転系の技」という3つの学習課 題から 1つを選択し，同一の学習課題を選択した 者同士でグループ学習を行うという形式で展開さ れた。本論では，この授業で後転とびを学習課題 として選択した学生の中から調査対象が選定され た。またこのグループの「課題練習」では，補 助者による直接的幇助を用いて後転とびの練習を 行う前に, 毎回, 以下のような 3 つの「予備練習」 を行わせた：(1)「2 人組で背中合わせで後方倒立 回転を行う」，(2)「約 $1 \mathrm{~m}$ の高さに積み上げたソ フトマットに向かって背面から後方へジャンプす る」，(3)「実施者の左右に 2 名の補助者を付けて 
記述日：月 日

氏 名

今日の授業の最後の頃にあなたが「バク転」を（補助してもらって，あるいは一人で） できた時のことを思い出して，以下の質問の（）の中の当てはまる項目に○印を付 けてください.

(1) $=$

(5)

(6) $=$

(8)

(9)

(10) $=$

1. 今日は「バク転」を（・やりたかったノ・どちらでもなかったノ・やりたくなかった）.

2.「バク転」をやっている時は，なんとなく

3.「バク転」をやっている時は，
$($ (・怖かったノ・どちらでもなかったノ・怖くなかった）.

4.「バク転」をやっている最中に，自分が後に移動しているのは

（・はっきりと分かる/・何となく分かる/・まったく分からない).

5.「バク転」をやっている最中に，自分が上に移動しているのは

(・はっきりと分かる/・何となく分かる/ままったく分からない).

6.「バク転」をやっている最中に，自分が回転しているのは

(・はっきりと分かる/・何となく分かる/・まったく分からない).

7.「バク転」をやった後に，今やった「バク転」がよかったかどうかは

(・はっきりと分かる/・何となく分かる/・まったく分からない).

8.「バク転」をやった後に，今やった「バク転」で，うまく蹴れたかどうかは (・はっきりと分かる／・何となく分かる／まったく分からない).

9.「バク転」をやった後に，今やった「バク転」で，腕の振りがうまくできたかどうか は（・はっきりと分かる/・何となく分かる/・まったく分からない).

10.「バク転」をやった後に，今やった「バク転」で腕の振りと蹴りがうまく合っていた かどうかは（・はっきりと分かる/・何となく分かる/・まったく分からない).

11.

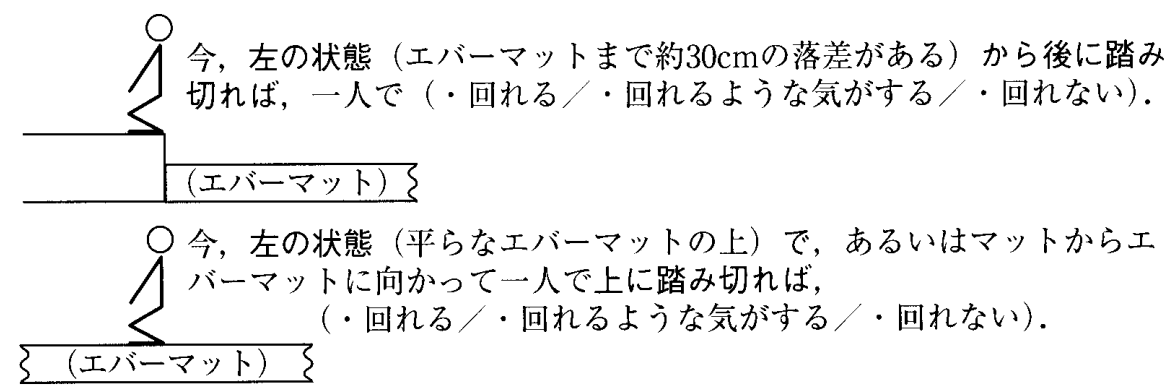

13. 今, 上の 12 状態から，意識して後に大きく移動するように「バク転」をしようと思 えば（・できる/・できるような気がする/・できない）。

14. 今，上の12の状態から，意識して上に高く跳び上がるように「バク転」をしようと思 えば（・できる/・できるような気がする/・できない）。

15. 今，上の 12 の状態から，「バク転」をやれば，「バク転」の着地の後に，ただちに真 上に安定してジャンプすることが

(・できる/・できるような気がする/・できない). 
直立姿勢から後方倒立回転を行う」.これらの予 備練習の後，学習者の習熟レベルに合わせて1名 ないしは 2 名の補助者を付けて, 踏切板の上から, ソフトマットの上で，あるいはマット上で後転と びの練習が毎回 20 分から 40 分行われた。

上に述べた授業で後転とびを学習課題として選 択した学生は，M2が19名（女子1名）, S2が17 名（女子 3 名），C2が17名（女子 2 名）であった (合計 53 名)。この 53 名の学生から女子学生 6 名 を除いた 47 名の男子学生に対して，以下の調査 が実施された。

（1）運動歴の調査：小学校から現在までの運動 歴を詳細に調査するために，初回の授業で，あら かじめ作成しておいた「体育および器械運動等に 関する調查用紙」を配布し，次週までにこの調查 用紙に記入して提出するよう指示した。指導者は， この調查用紙を回収した後に，一人一人の回答内 容を精査し，未回答や不明な部分については調査 対象者に直接質問して不足部分を補った。

（2）学習者自身による学習経過に関するレポー ト：初回の授業で，授業参加者の全員に対して， 授業中に自分が技を練習した時に何を意識してい たのか，どんな工夫をしようとしていたのかにつ いて，毎時間授業後に簡単なメモを書いておくよ うに指示した．同時に，一学期の授業がすべて終 了した後に，夏休みの課題として，このメモに基 ついて，自分の練習している技が授業を通してど のように変わっていったのかに関するレポートを 作成して提出しなければならないことが伝えられ た。

（3）質問紙による調查：初回の授業の「グルー プごとの課題練習」のところで，まずはじめに上 に述べた「予備練習」を行わせ，さらに幇助の什 方を練習させた後に, 補助者を付けて「後転とび」 を行う練習を抢よそ10 分程度行い，その後直ち に表 2 に示した「質問紙」に回答の記入を行わせ た。その際には，記入に先だって質問紙の内容と 記入の方法を口頭で説明し，さらに質問紙に関す る質問を受けるようにした。その後の授業では, 毎回授業終了前に 5 分程度の時間をとって質問紙 に記入させ，提出させた。
（4）指導者による学習者の形成位相の評価: 毎回の授業で，指導者は，授業中の観察を通して 上記 47 名の調査対象者が形成位相のどのあたり にいるのかをできるだけ細かく判定し，授業終了 後にその内容を，たとえば「探索位相の後半，も う少しでできる」といった簡単なコメントにして， 提出された質問紙の裹面の「指導者所見欄」に記 載した。

（5）ビデオ撮影：3回目の授業以降は，練習の 様子をビデオカメラで撮影し，その日の練習の最 後に各調查対象者の後転とびを一人ずつビデオに 収録した，その際，調査対象者には，後転とびの 出来が不満足な場合にはやり直してもよいという ことが伝えられていた。

（6）「できる」という回答に対する確認：「質 問紙」（表 2）の質問項目 11 と 12 に回れる」,

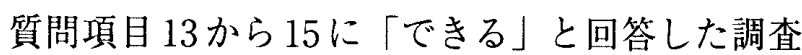
対象者がいた場合には，次の週の授業でその学生 に当該の項目を実施させ，その様子をビデオに収 録した．指導者はこの時の状況を観察し，その学 生の実施内容を「できている/だいたいできる／ できない」の3段階で評価し，その時の詳細を前 週の質問紙裏面の「指導者所見欄」に記入した。

（7）指導者の予想に反する回答に関する追加調 查：毎回，「質問紙」（表2）の提出後に，指導者 によって回答内容が精査され，(4) で述べた指導 者による形成位相の評価から著しくかけ離れてい ると思われる回答が見出された場合には，次の週 の授業で当該の学生になぜそのように回答したの かについて口頭で確認もしくは質問し，その質問 の内容と結果を前週の質問紙裏面の指導者所見欄 に転記した。

\section{III 考察}

\section{1. 考察対象の選定}

考察対象者を限定するために，まずはじめに， すでに述べた 47 名の調查対象者の中から久席の 多かった者 1 名が除外された。さらに，本論の目 的は後転とびができないところから始まってでき るようになるまでの学習過程を追跡することにあ 
学習者O

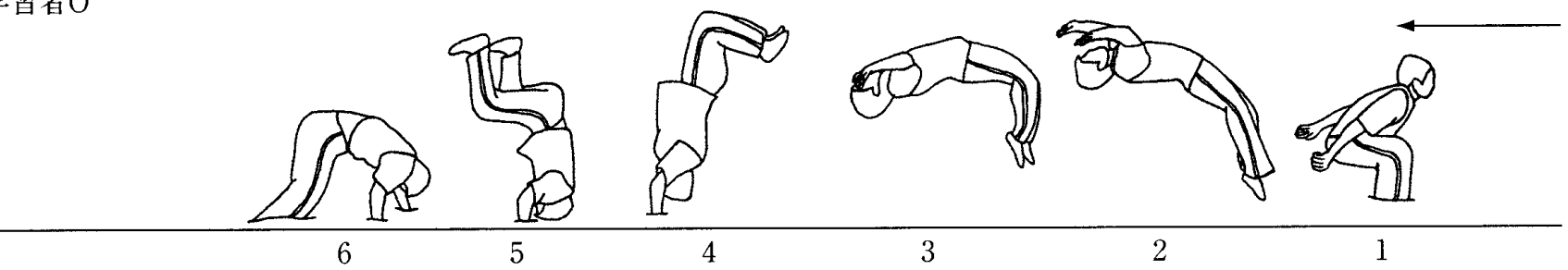

学習者 $\mathrm{K}$

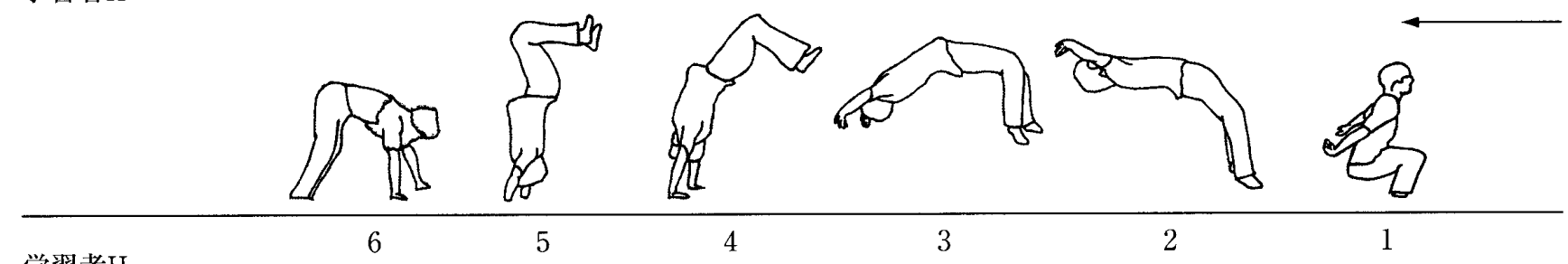

学習者 $\mathrm{H}$

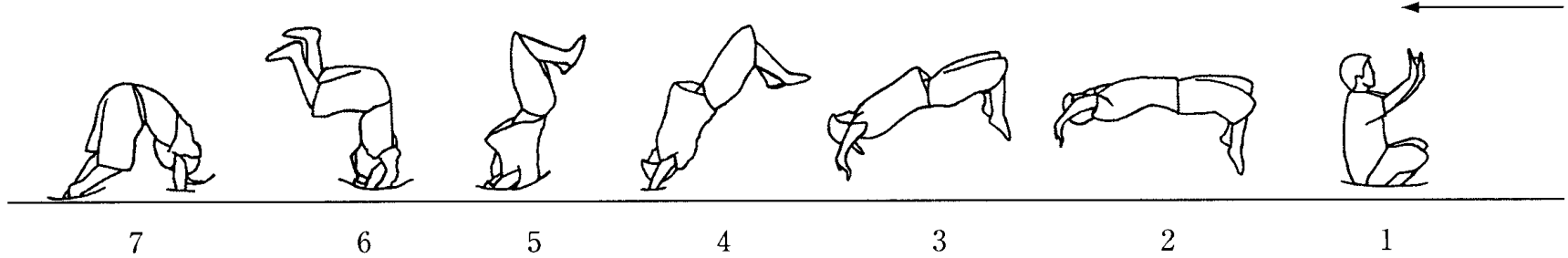

図1 最終回の授業の最後に行った後転とび（撮影日：7月9日）

るので，第二段階として，本論のIIの 4 の（1） で述べた運動歴の調査結果に基づいて，「以前に 後転とびの練習をしたことがある者」17名と 「以前に練習したことがなく，授業では最後まで できるようにならなかった者」3名が除外された。 続いて第三段階として，IIの4の（4）で述べた 「指導者による学習者の形成位相の評価」に基づ いて，「授業では 1 度はできるようになったが， その後の練習の中でできなくなってしまったり， 蹴ると同時に体をひねってしまうようになった 者」4名が除外された。

さらに第四段階として，ごく短期間のうちに課 題を達成してしまった学習者は今回の考察から除 外することにした。今回の調査では，授業時間内 の個人の行動を逐一詳細に記録してはいなかった ので，一回の授業時間内に生じた形成位相の変化 を厳密に追跡することは不可能だと判断したから である。このために，すでに述べた「指導者によ る学習者の形成位相の評価」に基づいて，「3回 目までの授業で一人でできるようになってしまっ た者」17名が考察刘象から除外された。こうし て残された 5 名の学習者の中から，さらに第五段
階として，「授業を 1 回以上欠席したことがある 者」2名が除外された。

以上の手続きを通して，本論では，「後転とび」 が「できない」ところからはじまって，比較的長 時間（4回以上）かけて，大きな学習障害に遭遇 することもなく順調に「できる」ようになったと 考えられる 3 名の学習者 $(\mathrm{O}, \mathrm{K}, \mathrm{H})$ (図 1 参照) が考察対象者として選定された。

\section{2. 考察資料の作成}

はじめに，考察対象者として選ばれた 3 名の学 習者について，本論のIIの4の（3）で述べた 「質問紙による調查」の結果をまとめて，回答結 果集計表（表3）が作成された。この回答結果集 計表に示された 3 名の学習者の折線グラフの変化 を学習プロセスの展開に沿って追跡したところ， 以下のことが明らかになった。

すでに本論のIの 2 で述べたように，質問項目 1 は「学習志向性」の存在を，質問項目 2 と 3 は 「体感能力の芽生え」をとらえることを意図した 質問であった。しかし，この3つの質問項日に対 する 3 名の学習者の回答には，事前に想定された 

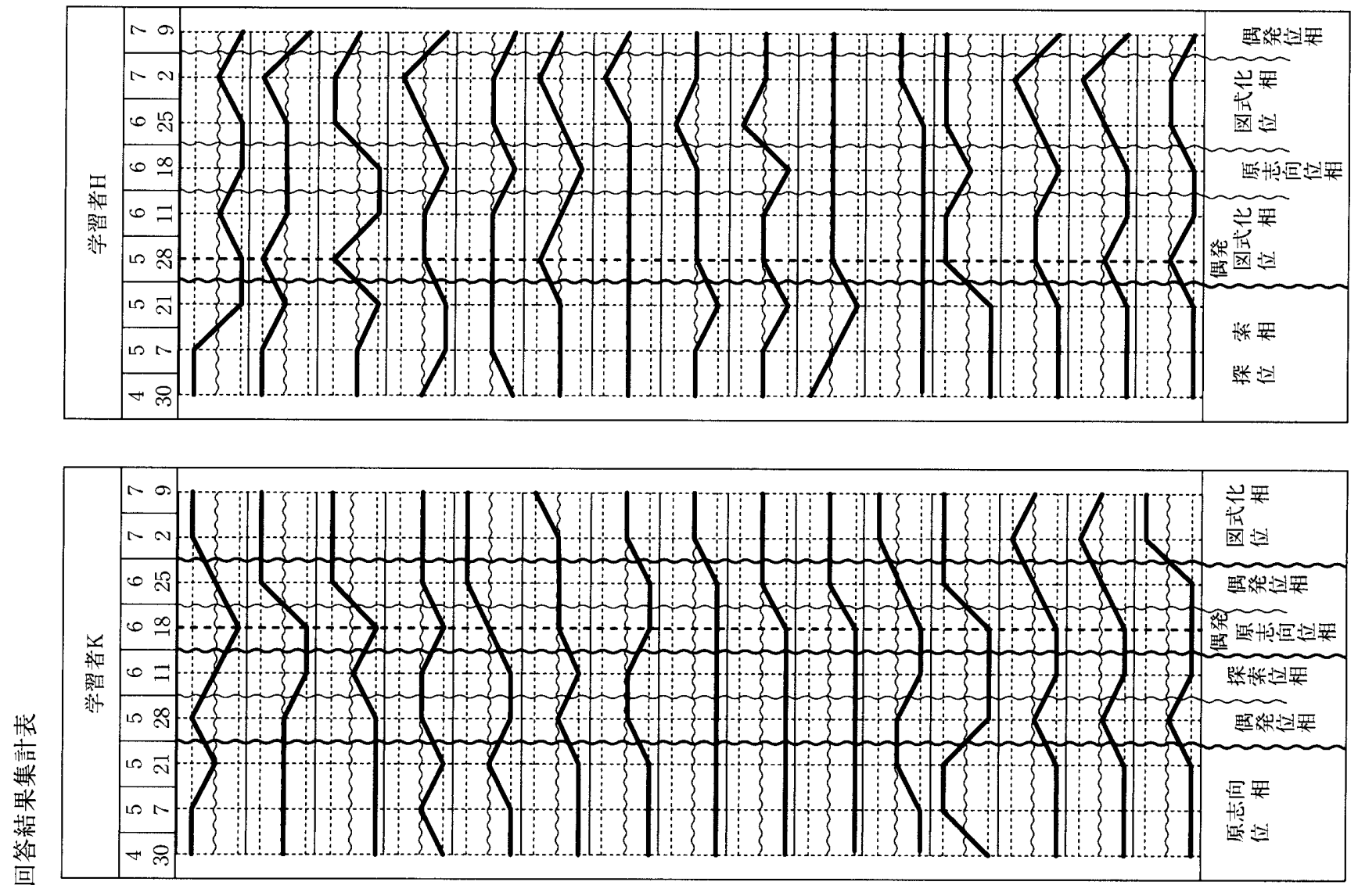

粆

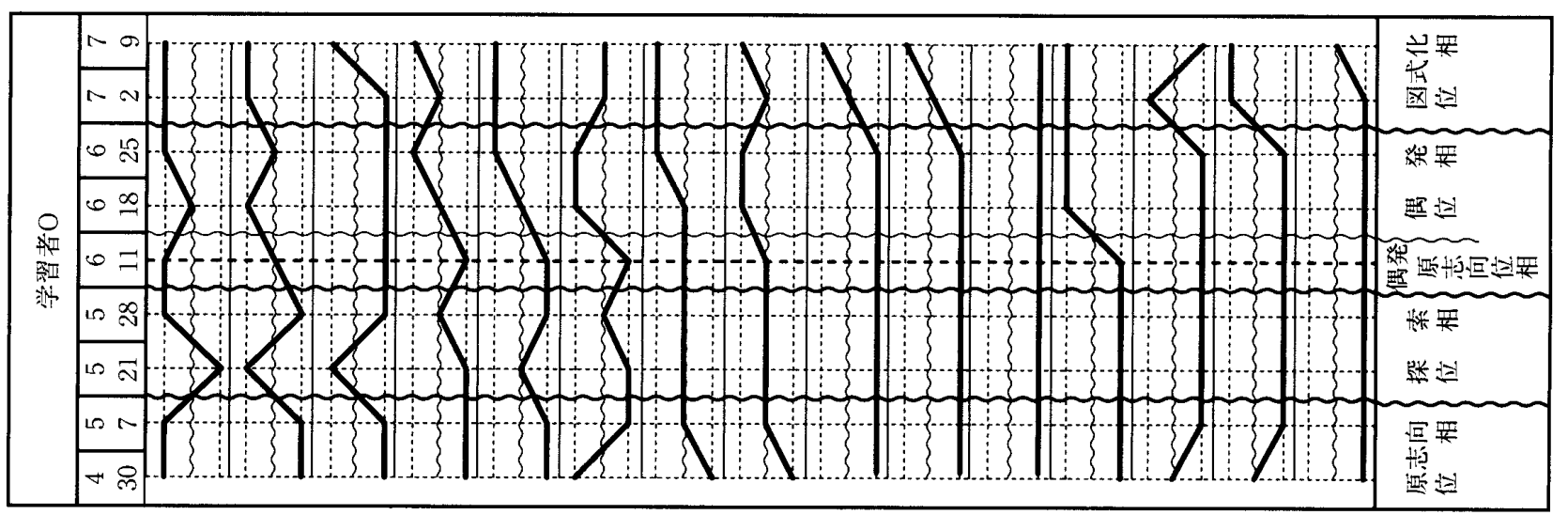

\begin{tabular}{|c|c|c|c|c|c|c|c|c|c|c|c|c|c|c|}
\hline 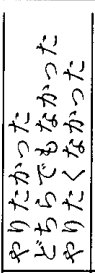 & 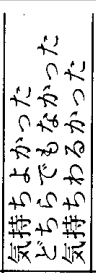 & 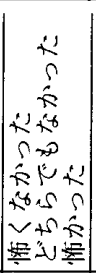 & 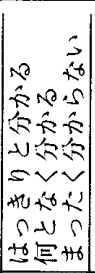 & 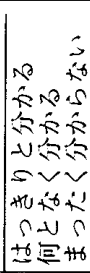 & 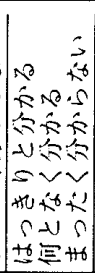 & 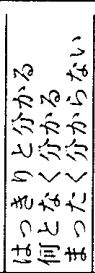 & 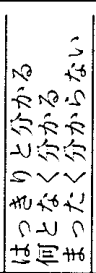 & 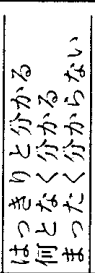 & 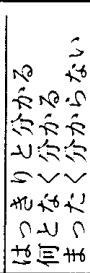 & 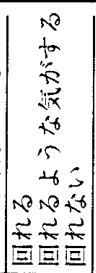 & 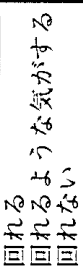 & 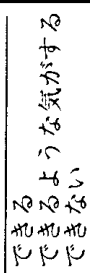 & 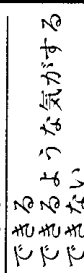 & 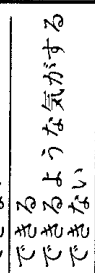 \\
\hline 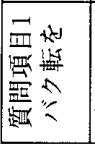 & 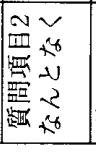 & 詈 & 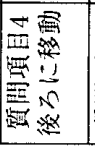 & 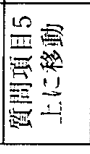 & 曹 & 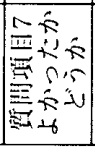 & 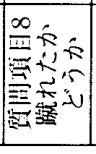 & 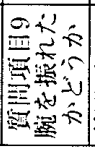 & 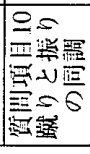 & 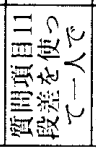 & & 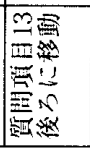 & 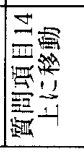 & 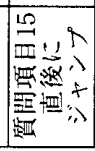 \\
\hline
\end{tabular}


「学習の進展にともなって回答欄の右から左（表 3では下から上）へと移っていく傾向」は認めら れなかった。それゆえ，第一には，この回答結果 集計表からは，質問項目 1 から 3 の内容が質問意 図を達成するには不適切なものであったというこ とが明らかになった。これに対して，質問項目 4 から15の回答結果には，この事前に想定された 傾向が，さらには，この傾向ははじめに番号の小 さい質問項目で，その後次第に番号の大きな質問 項目で認められるようになるということが確認で きた。すなわち，第二には，これらの質問項目の 回答結果には，すでにIIの 2 に示した予想がほぼ 当てはまるということが明らかになったのであ る。

この結果を受けて，本論ではさらに，運動感覚 能力のこの発生順にしたがって後転とびの形成位 相を識別するために，形成位相に関する金子 （2002，pp.417-430）の特性描写を参考にして， 質問項目 4 から 15 の回答に以下のような基準が 設定された。

<探索位相 $>$ : 質問項目 $4 ， 5 ， 6$ の回答のいず れか 1 つが第二段階以上にあり，かつ質問項目 7 ,

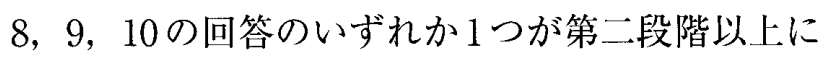
ある。

く偶発位相〉：まぐれ当たりの形態発生から， 質問項目 11 と 12 の回答のいずれか 1 つが第二段 階以上にあるところまで。

<図式化位相 > : 質問項目 4，5，6と 7，8，9, 10 の回答のすべてが第二段階以上にあり，かつ

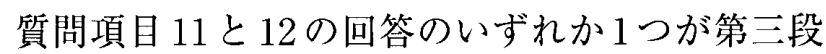
階にあり，質問項目 $13 ， 14 ， 15$ の回答のいずれ

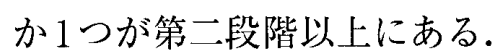

続いて，この基準にしたがって，表3の中に学 習者ごとに形成位相の区切りが書き入れられた (表3の下の闌)．なお，表3の下の闌の「偶発」 は，後転とびがはじめて「まぐれ当たり」で発生 した時期を示している。この時期は，本論のII の4の（2）に示したレポートに基づいて特定さ れた。これに続いて，個々の学習者の後転とびの 形成位相の展開様相を概観するために, 表 4 から 6 6゙作成された。これらの表では，上に述べたレ
ポートの記述内容から重要と思われる部分を抜粋 したものが真ん中にまとめられ，その左側にはこ の記述内容から推測される形成位相の展開が，右 側には以下の考察に基づいて明らかにされた形成 位相の展開が示されている.

\section{3. 学習者ごとの形成位相の展開}

1) 学習者 $O$

Oのレポートの記述からは，後転とびの学習が 原志向位相 $\rightarrow$ 偶発位相 $\rightarrow$ 図式化位相という順に進 んでいったことしか読み取れない（表4の左側参 照).これに対して，表4の右側に示したように， 回答結果集計表（表3）に基づけば，Oは原志向 位相（嫌な気がしない段階）から出発して，5月 21 日（3回目）に探索位相（分かるような気がす る段階）に達し，6月11日（5回日）の授業で後 転とびが「まぐれ当たり」でできてしまった時 （偶発位相に入った時）には原志向位相（嫌な気 分はしないが，ほとんど何も分からないという状 態）にまで回州してしまい，その後6月25日（7 回目）まで偶発位相（できるような気がする段階） にとどまっていて，7月 2 日（8回目）にようや く図式化位相（いちおうできるという段階）に達 したことが分かる。

\section{2）学習者 $\mathrm{K}$}

レポートの記述内容に基づけば， $\mathrm{K}$ の後転とび の学習は原志向位相から出発して探索位相 $\rightarrow$ 偶発 位相 $\rightarrow$ 図式化位相へと順調に進んでいったように みえる (表5の左側参照)。これに対して，回答 結果集計表（表3）からは，原志向位相 $\rightarrow$ 偶発位 相 $\rightarrow$ 探索位相 $\rightarrow$ 原志向位相 $\rightarrow$ 偶発位相 $\rightarrow$ 四式化位 相というように，学習者 $\mathrm{K} の$ 形成位相がめまぐ るしく変化していたことが分かる．さらに，表 3 の質問項目 12 の回答をみると，5月 7 日（2回目） と 5 月 21 日（3回目）にはエバーマット上で一人 で「回れる」と答えていたのに，5月28日（4回 目）には突然「回れない」に変わっている，Kの 回答のこの突然の変化は，指導者による授業後の 回答結果の精査を通してその日のうちに発見さ れ，指導者は次の週にこの変化について Kにロ 頭で質問を行っている。前の週（5月28日）の質 
表4 学習者Oの形成位相の展開（レポートの文中のゴシックは著者による）

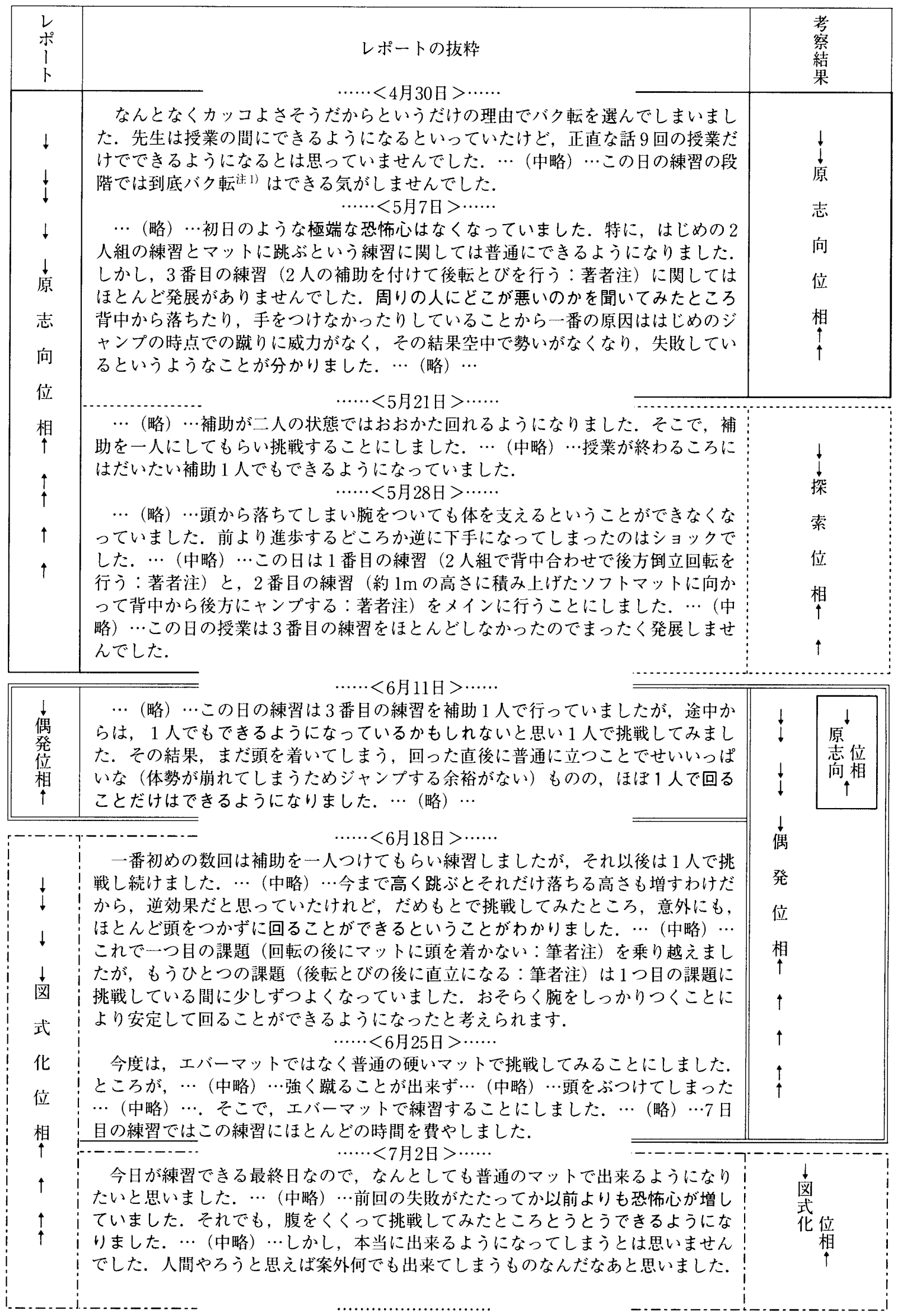


表 5 学習者 $\mathrm{K}$ の形成位相の展開（レポートの文中のゴシックは著者による）

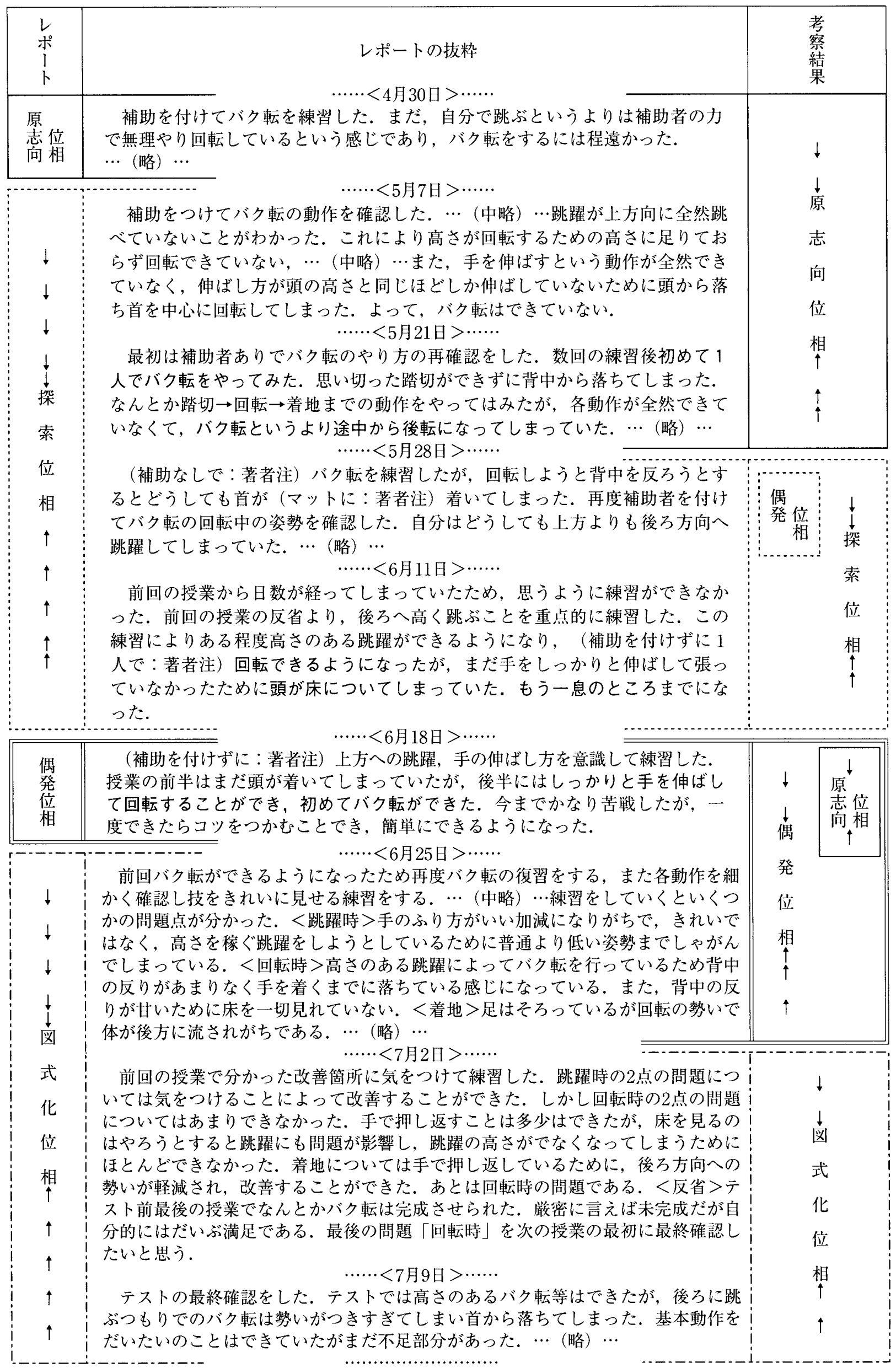


問紙裏面の指導者所見欄（本論のIIの 4 の（7） を参照）には，この時の $\mathrm{K} の$ 回答が次のように 記載されている：「回れるようにはなったけど， まだバク転にはなっていないので，回れないと回 答した.」また，5月21日（3回目）のレポート には，「バク転というより途中から後転になって しまっていた」と述べられている（表5参照）。 それゆえ，質問項目 12 に対する 5 月 7 日と 5 月 21 日の「回れる」という回答は，はじめは空中で, 続いてマットに頭部が接触した状態で腹屈頭位の まま後に回ることを意味していたと考えられる。 この推察は，この日に撮影された後転とびのビデ 才映像によって確認された。 Kが，補助者を付け ずに，一人でこの状態で「回れる」ようになった のは6月11日（5回目）である。しかし，Kはこ の時の質問紙の質問項目 12 に「回れない」と回 答しており (表 3 参照)，レポートでも「頭が床 についてしまっていた」ので「もう一息のところ」 だったと評価している (表 5 参照)。これに対し て，「しっかりと手を伸ばして回転することがで き，はじめてバク転ができた」のは 6 月 18 日（6 回目）である（表 5 参照）。それゆえ，後者の基 準に従って判断すれば，5月7日と 5 月 21 日の質 問項目 12 に対する回答は「回れない」と書き改 められるのが妥当であると考えられる。これに従 って，Kの5月28日（4回目）の形成位相は「偶 発位相」から「探索位相」に変更されることにな る。

この変更に従って，Kの形成位相の展開は以下 のように解积することができる。すなわち，Kは 原志向位相から出発し，5月28日（4回目）に探 索位相に進み，6月18日（6回目）には，学習者 Oの場合と同様に，後転とびの偶然の発生にとも なって原志向位相への回帰が生じ，さらに 7 月 2 日（8回目）には図式化位相に達し，そのままの 状態で一学期の授業を終了したのである（表5の 右側参照)。

\section{3）学習者 $\mathrm{H}$}

レポートの記述からは，Hの後転とびの学習は 探索位相から出発して，5月 28 日（4回目）には 偶発位相，6月 11 日（5回目）には図式化位相に
達していたことが推測される。また，Hは6月 11 日（5回目）の授業で突然「首から落下」してし まい，「恐怖心がまたあることに気がつく」が， この日のうちに一人で何度も練習して「感覚は取 り戻せたと思う」という状況にまで回復している。 それゆえ，レポートの記述からだけでは，Hは 6 月 11 日以降は順調に図式化位相にとどまってい たと考えられる (表6の左側参照)。しかし，H のレポートは 6 月 11 日で突然終わってしまい, その後に「感想」という形で，「バック転はやっ ぱり難しい」という記述が残されている（表6参 照).

これに対して，回答結果集計表（表3）に基づ けば，Hは5月 28 日（4回目）の偶然の発生を経 てその日の内に一気に図式化位相にまで進んでし まったこと，6月18日（6回目）の授業では原志 向位相に，7月9日（9回目）の授業では偶発位 相への回㷌が生じていたことが分かる。このこと は，さらに，Hが5月 28 日（4回目）の授業の最 後に行った後転とびのビデオ映像（図2）と7月 9 日の授業の最後に行った後転とびのビデオ映像 （図1）を比較してみることによっても裏づけら れる。

表 3 の質問項目 3 の回答を見ると, $\mathrm{H}$ は 5 月 28 日（4回目）には「怖くなかった」と答えていた にもかかわらず，「首から落下」した 6 月 11 日 （5回目）に突然「怖かった」に変わり，この恐 怖感はそのまま6月18日（6回目）まで引きずら れていたことが分かる。また，7月9日（9回目） の質問項目 1 から 3 の回答には，恐怖感が発生し 学習意欲が低下していたことが示されている。 そ れゆえ，Hの図式化位相における2回の回帰現象 は恐怖心によってひき起こされたものと考えられ る、したがって，Hは，この回帰現象によって消 滅してしまった移動に関する運動感覚能力（表3 の質問項目 4，5）を取り戻すことことによって， 再び安定して後転とびを行えるようになると思わ れる。 
表6 学習者 $\mathrm{H} の$ 形成位相の展開（レポートの文中のゴシックは著者による）

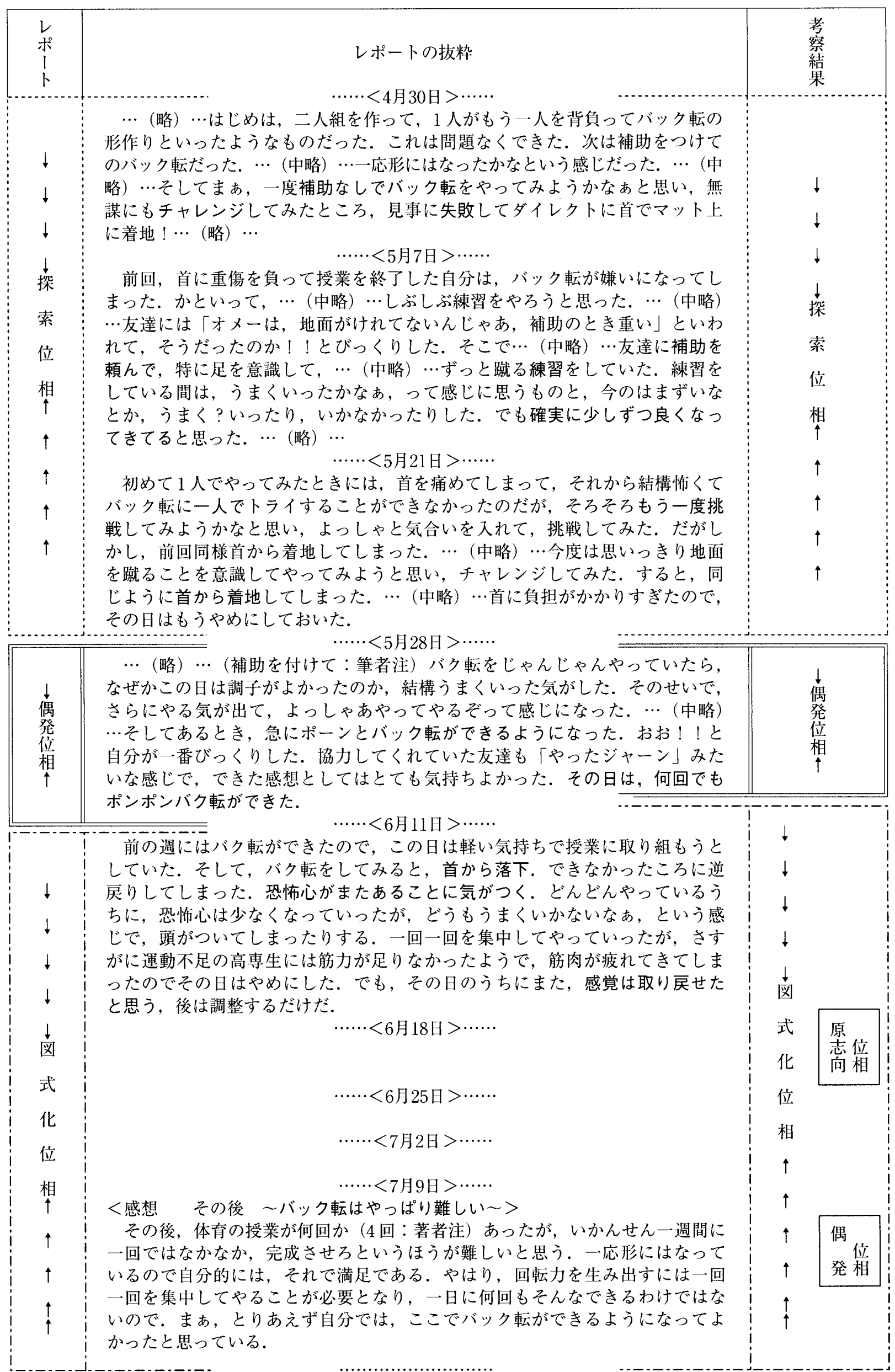




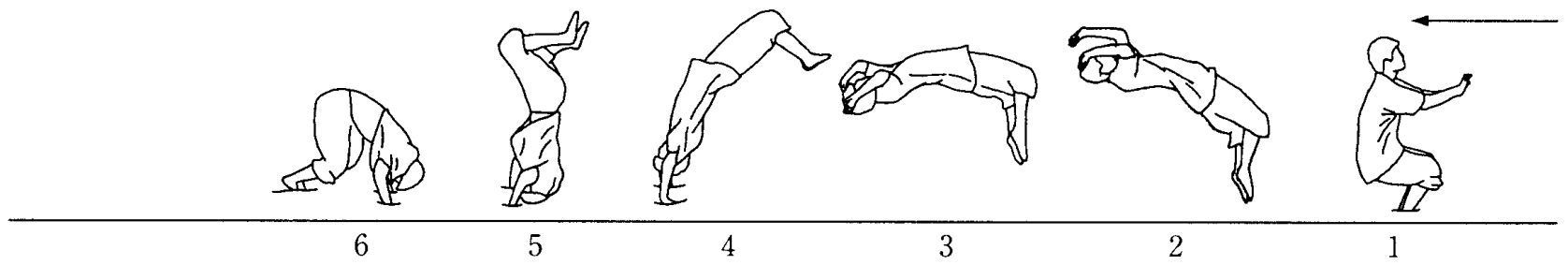

図2 学習者 $\mathrm{H}$ が4回目の授業の最後に行った後転とび（撮影日：5月 28 日）

\section{IV 結 論}

本論では, 質問紙の「回答結果集計表」，「学習 者自身による学習経過に関するレポート」,「授業 場面を撮影したビデオ映像」を用いて，3人の学 習者の後転とびの学習経過が詳細に考察された。 この考察を通して明らかにされた学習者ごとの形 成位相展開の様相（IIIの3の（1）から（3））は, 論文の全体が完成した後（2004年 2 月 17 日）に， 考察結果の妥当性を確保するために 3 人の学習者 に提示され，その内容が本人の実体験に矛盾して いないかどうかが確認された。この結果, 本論で 作成された質問紙を用いることによって，学習者 自身のレポートの記述や指導者の観察からでは読 み取れない，運動の形成位相の変化を細かく識別 できるということが明らかになった。

したがって，本論で作成された質問紙を用いて 個々の学習者の後転とびの今の形成位相を識別 し，これに基づいて次の形成位相に必要とされる 運動感覚能力を具体的な学習目標として学習者に 提示することができる。また，この質問紙を用い て回帰位相の識別もできるので，学習障害に陥っ ていってしまった学習者に，その際に消滅してし まった運動感覚能力の獲得を目指させることによ つて，学習障害を克服させることも可能になる.

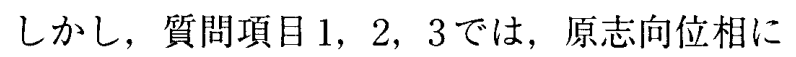
おける能力発生を的確にとらえることはできなか った.これについては, 被験者と質問内容につい て，さらにその妥当性を検討することが求められ る。また，学習者 $\mathrm{H} の$ 考察からは，後転とびの 学習の場合には「着手を先取りできる能力」が発 生していない状態でも「回れる」（表3の質問項
目 11 と 12 を参照）という運動感覚能力が発生し てしまう可能性が示唆されている。 それゆえ，後 転とびの学習における運動感覚能力の発生様態を さらに詳しく解明していくには，質問紙に着手の 先取り能力の発生に関する質問項目を加えること が必要であると思われる.

今後は，これらの問題を十分に検討した上で， 質問項目をできる限り減らし，学習者が容易に回 答できる質問紙を作成することによって，一回の 試行ごとに形成位相がどのように変化していくの かを短期的にとらえる方法を開発することが求め られる。ささらにまた，本論では取り上げられなか った，自在化位相を識別できる質問項目を設定し て長期の形成位相の展開を縦断的にとらえる方法 を開発することも，今後の課題として残されてい る。

\section{注}

注 1）本論の考察対象に選定された 3 名の学習者は,

「学習者自身による学習経過に関するレポート」 の中で，「後転とび」を示すために「バク転」も しくは「バック転」の用語を用いている。

\section{文献}

Buytendijk. F.J.J. (1956) Allgemeine Theorie der menschlichen Haltung und Bewegung. SpringerVerlag: Berlin.

浜渦辰二（1995）フッサール間主観性の現象学. 創 文社：東京.

ヘルト：浜渦辰二訳（2000）20世紀の屝を開いた哲 学. 九州大学出版会：福岡.

金子明友（1972）体操競技のコーチング. 大修館書 店: 東京, pp. 250-254. 金子明友（2002）わざの伝承. 明和出版：東京. 
木田 元・野家啓一・村田純一・鷿田清一編（1994） 現象学事典. 弘文堂：東京.

メルローーポンティ：竹内芳郎・小楨孝訳（1967） 知覚の現象学. みすず書房 : 東京, pp. 184-233.

Merleau-Ponty, M. (1966) Phänomenologie der
Wahrnehmung. Walter de Gryuter \& Co.: Berlin, S. 131-168.

平成 16 年 3 月 12 日受付) 